\begin{tabular}{lr}
\hline PRACE NAUKOWE UNIWERSYTETU EKONOMICZNEGO WE WROCLAWIU \\
RESEARCH PAPERS OF WROCLAW UNIVERSITY OF ECONOMICS & nr 472 • 2017 \\
\hline Dylematy zarządzania kosztami i dokonaniami & ISSN 1899-3192 \\
& e-ISSN 2392-0041
\end{tabular}

\title{
Tomasz Kondraszuk
}

Szkoła Główna Gospodarstwa Wiejskiego w Warszawie e-mail: tomasz_kondraszuk@sggw.pl

\section{RACHUNEK KOSZTÓW NA POTRZEBY ZRÓWNOWAŻONEGO ROZWOJU W ROLNICTWIE* COST ACCOUNTING FOR SUSTAINABLE DEVELOPMENT IN AGRICULTURE}

DOI: $10.15611 /$ pn.2017.472.13

JEL Classification: O3

Streszczenie: Celem opracowania jest przedstawienie najważniejszych uwarunkowań zrównoważonego rozwoju w kontekście możliwości doskonalenia rachunku kosztów w rolnictwie przy wykorzystaniu dorobku teorii ogólnej rachunkowości zarządczej (ekonomiki przedsiębiorstw) ze szczególnym uwzględnieniem TDABC. Dotychczasowe obawy, dotyczące niemożności przenoszenia zasad rachunku kosztów z działalności pozarolniczej do rolnictwa nie potwierdzają się. Wyniki badań modelowych zastosowania nowoczesnych koncepcji rachunków kosztów w rolnictwie na przykładzie TDABC dają pozytywne rezultaty. Dodatkowe ograniczenia wynikające z zasad zrównoważonego rozwoju nie zmieniają tego faktu. Należy przyjąć, że wnioski co do innych koncepcji, takich jak rachunek kosztów docelowych z opcją KAIZEN, rachunek kosztów cyklu życia produktu, rachunek kosztów TQM czy też zasobowo-procesowy rachunek kosztów (ZPRK), będą podobne.

Slowa kluczowe: rolnictwo, rachunek kosztów, zrównoważony rozwój, TDABC.

Summary: The aim of the paper is to present the most important conditioning of sustainable development in the context of opportunities for the improvement of cost accounting in agriculture using the achievements of the theory of general management accounting (business economics) with special focus on TDABC. The current concerns about the impossibility to transfer cost accounting principles of non-agricultural activities to agriculture are not confirmed. Model results to apply modern concepts of cost accounting in agriculture for example $\mathrm{TDABC}$ produce positive results. Additional restrictions resulting from the principles of sustainable development do not change this fact. It is assumed that the conclusions of other concepts, such as target costing with "Kaizen" costing, the product life cycle costing, TQM, or resource and process consumption accounting (RPCA) will be similar.

Keywords: agriculture, cost accounting, sustainable development, TDABC.

* W opracowaniu wykorzystano wyniki badań grantu badawczego nr 3688/B/H03/2011/40 pt. „Rachunek kosztów w rolnictwie w warunkach zrównoważonego rozwoju”. 


\section{Wstęp}

Rolnictwo jako dział gospodarki narodowej podlega ciągłej ewolucji i dostosowuje się do aktualnych potrzeb społeczno-gospodarczych. Właściwy rachunek kosztów przeciwstawiający dokonaniom koszty ich osiągnięcia i pozwalający na ocenę ich racjonalności ma do odegrania ważną rolę. Wybór tematu opracowania jest nawiązaniem do dwóch bardzo ważnych dylematów obecnego rolnictwa. $Z$ jednej strony, rachunek kosztów sugeruje konieczność racjonalnego i oszczędnego gospodarowania, a z drugiej strony, zrównoważony rozwój nakłada na nas konieczność uwzględniania uwarunkowań społecznych i środowiskowych działalności rolniczej, czego następstwem jest wzrost kosztów wytwarzania. Rachunek kosztów w rolnictwie wykracza poza kalkulację kosztu jednostkowego i analizę uzyskiwanych cen. Konieczne jest zidentyfikowanie i określenie przyczyn oraz celów ponoszonych nakładów i zużycia określonych zasobów w kontekście ekonomicznym, społecznym i środowiskowym.

W literaturze ekonomiczno-rolniczej ugruntowało się przekonanie o niemożności przeniesienia zasad rachunku kosztów (ogólnie wyników) z działalności pozarolniczej (przemysłu i handlu) do rolnictwa. Za główną przyczynę takiej sytuacji uznano organiczny charakter gospodarstwa rolniczego. Ostrej krytyce poddane było obliczanie „pełnych” kosztów jednostkowych produktów rolniczych jako kalkulacji pracochłonnych, a jednocześnie nieprzydatnych do podejmowania decyzji. Ryszard Manteuffel [1984] pisał: „obliczone wielkości jednostkowych kosztów własnych nie obrazują rzeczywistości gospodarczej, są mylące, nie mogą więc być podstawą do podejmowania decyzji, zarówno w skali poszczególnych gospodarstw, jak i całości naszego rolnictwa. Stanowią one jedynie rodzaj zasłony dymnej, ułatwiającej w niektórych wypadkach uzasadnienie różnych fałszywych decyzji. Są one wyrazem mętniactwa w stosowaniu pozorowanego rachunku kosztów". Tezy te kontynuowali i rozwijali m.in. Ziętara i Kondraszuk [1986, 1987] oraz Kondraszuk [1987a, b]. W praktyce rolniczej stosowane były przede wszystkim najprostsze formy rachunku ekonomicznego. Wykorzystywane były kalkulacje niepełne, oparte na kosztach bezpośrednich/zmiennych, wpływających w sposób bezpośredni na wielkość i wartość produkcji. Na tej podstawie możliwe było stosowanie popularnych kalkulacji różnicowych ${ }^{1}$, pozwalających na wybór przez rolnika jednego z dwóch (lepszego) wariantów decyzyjnych.

Przykład zastosowania kalkulacji różnicowych dla oceny programów środowiskowych opisał Kondraszuk [2013]. Na gruncie ekonomiki i organizacji gospodarstw w publikacjach i badaniach naukowych próbowano wykorzystywać bardziej nowoczesne narzędzia rachunku ekonomicznego, oparte na programowaniu linio-

${ }^{1}$ „Uważa się, że podstawowym narzędziem w podejmowaniu decyzji w gospodarstwie rolniczym są kalkulacje różnicowe. Posługując się nimi, można ustalić: właściwy kierunek produkcji, odpowiedni poziom intensywności, najbardziej efektywne technologie oraz najodpowiedniejszą formę organizacyjną przedsiębiorstwa" [Jóźwiak, Kierul 1985, s. 5-6]. 
wym. Problematyka przydatności modeli liniowych do wspomagania podejmowania decyzji była opisywana przez wielu autorów ${ }^{2}$. Kwestia ich budowy w warunkach dążenia do zrównoważonego rozwoju została opisana m.in. w pracy Kondraszuka [2016].

Celem opracowania jest przedstawienie najważniejszych uwarunkowań zrównoważonego rozwoju w kontekście możliwości doskonalenia rachunku kosztów w rolnictwie przy wykorzystaniu dorobku teorii ogólnej rachunkowości zarządczej (ekonomiki przedsiębiorstw) ze szczególnym uwzględnieniem TDABC ${ }^{3}$.

\section{Uwarunkowania zrównoważonego rozwoju w rolnictwie}

Nowy zrównoważony model rozwoju rolnictwa, w którym cele społeczne i gospodarcze są w pełni zintegrowane z celami środowiskowymi, został zapoczątkowany w 1992 roku reformą Wspólnej Polityki Rolnej (WPR) pod przewodnictwem komisarza MacSharry'ego. Zapoczątkowała ona tworzenie nowego wizerunku rolnictwa europejskiego, opartego na trwałym wzroście i zrównoważonym rozwoju obszarów wiejskich. To właśnie ścisłe powiązanie rolnictwa z warunkami środowiska naturalnego wytycza nowoczesnemu rolnictwu dodatkowe zadania. Rolnicy starają się postępować racjonalnie i podejmują decyzję o kierunkach rozwoju w oparciu o spodziewane korzyści i ponoszone koszty. Konieczne jest, aby w rolnictwie szeroko rozumiany rachunek kosztów (ekonomiczny) uwzględniał również efekty zewnętrze oraz nakłady i utracone korzyści z tytułu usług na rzecz ochrony środowiska i podporządkowania się zasadom zrównoważonego rozwoju ${ }^{4}$. Naprzeciw tym wymogom wychodzi ekonomia behawioralna. W odróżnieniu od ekonomii tradycyjnej, podejście behawioralne dostarcza wielu argumentów odnośnie do tego, aby w miejsce maksymalizacji wartości i pomnażania bogactwa akcjonariuszy za podstawowy cel działalności przyjąć dążenie do zrównoważonego rozwoju i budowę pozytywnych relacji w biznesie.

Paradygmat ekonomii neoklasycznej zakładał, że indywidualne decyzje podmiotów gospodarczych dzięki mechanizmom rynkowym doprowadzą do maksymalizacji dobrobytu w skali makroekonomicznej. Obecnie ekonomia instytucjonalna zanegowała założenie zerowych kosztów transakcyjnych, konkurencji doskonałej i pełnej informacji dla wszystkich uczestników rynku. Uświadomiono sobie występowanie efektów zewnętrznych działalności gospodarczej oraz globalnych problemów ekologicznych, które muszą być rozwiązywane przez powołane do tego insty-

\footnotetext{
2 Obszerne omówienie ich przydatności i etapów rozwoju zestawił Gędek [2009].

3 Opis uwarunkowań stosowania rachunku TDABC w rolnictwie zawarto w opracowaniu [Kondraszuk 2010].

${ }^{4}$ Przedmiotem zainteresowania ekonomii jako nauki powinna być nie tylko gospodarka, lecz także cały makrosystem składający się ze społeczeństwa, gospodarki i środowiska naturalnego. Wywołuje to również potrzebę uwzględniania oprócz optimum indywidualnego, także optimum społecznego zapewniającego sprawiedliwość wewnątrzpokoleniową, jak i międzypokoleniową.
} 
tucje i długofalową politykę państwa. Idea zrównoważonego rozwoju stanowi nowe wyzwanie dla rachunku ekonomicznego zarówno w skali mikroekonomicznej, jak i makroekonomicznej.

\section{Kierunki ewolucji rachunku kosztów w rolnictwie}

Rachunek kosztów był stosowany od zarania dziejów. Jego zakres i stosowana metodyka zmieniały się wraz z postępem technicznym i rozwojem ekonomiczno-społecznym poszczególnych krajów. Wszelkie wybory dokonywane były w oparciu o mniej lub bardziej sformalizowany rachunek kosztów, któremu przeciwstawiane były odnoszone korzyści. Nowoczesny rachunek kosztów datuje się od drugiej połowy XIX wieku, gdy rozwinęła się teoria ekonomiki i organizacji przedsiębiorstw, a rachunek kosztów stał się elementem systemu rachunkowości.

Pod koniec XIX wieku dało się zauważyć duże zróżnicowanie w ujmowaniu i rozliczaniu nakładów oraz kosztów pomiędzy rolnictwem a handlem i przemysłem. Tak zwana księgowość kupiecka nie przyjęła się w rolnictwie. Próby jej wdrożenia w gospodarstwach rolniczych zakończyły się niepowodzeniem. Stosowano w dalszym ciągu, oparty na systemie kameralnym, uproszczony wariant księgowości pojedynczej (syntetycznej). Sprowadzał się on do rejestracji stanów i obrotów naturaliami z jednoczesną ewidencją zmian stanu środków pieniężnych. Metoda ta określana jest obecnie jako metoda kasowa (neokameralna, kasowa weryfikowana), dla odróżnienia od ogólnie obowiązującej metody memoriałowej. Znalazła ona zastosowanie w ramach zunifikowanego systemu rachunkowości gospodarstw rolniczych (ZSRGR) ${ }^{6}$.

Obecnie rolnictwo jest traktowane jako składowa szeroko rozumianego agrobiznesu, gdzie mamy do czynienia z przedsiębiorstwami przetwórczymi i handlowymi, połączonymi często z działalnością rolniczą. Wydaje się więc, że konieczne staje się łączenie i ujednolicanie pojęć stosowanych w ekonomice i organizacji wszystkich przedsiębiorstw oraz stworzenie jednolitego systemu pojęć, w tym również w ramach rachunku kosztów. Jednak musi to być świadomy, ewolucyjny proces przeprowadzenia adaptacji teorii ogólnej rachunku kosztów do warunków rolnictwa.

5 Według R. Manteuffla [1965, s. 267], „W szerokiej praktyce księgowość kameralna dominowała w rolnictwie do końca XIX w., a i obecnie jest jeszcze dosyć rozpowszechniona w niektórych krajach w nieco zmienionej formie jako księgowość neokameralna".

6 W 1995 roku powołano grupę roboczą ds. opracowania systemu rachunkowości dla gospodarstw. Przygotowała ona założenia ZSRGR, który stał się podstawą opracowania polskiego FADN. W okresie 1996-2000 ZSRGR był prowadzony w kilkudziesięciu tysiącach gospodarstw przez młodych rolników korzystających z preferencyjnych kredytów na rozwój gospodarstw. 


\section{Wyniki badań}

W literaturze dotyczącej działalności pozarolniczej (handlowej, przemysłowej itd.) można znaleźć wiele propozycji systemów rachunku kosztów. Na świecie pojawiły się nowe koncepcje rachunku kosztów, polegające na próbach podziału kosztów pośrednich na poszczególne działalności, pozwalające na analizę i ocenę opłacalności wytwarzanych produktów i usług ${ }^{7}$ oraz na potrzeby planowania ${ }^{8}$.

Podstawowe pytanie brzmi: czy i w jakim zakresie można adaptować rachunek kosztów stosowany w ogólnej teorii ekonomiki przedsiębiorstw do warunków rolnictwa? Jest to zagadnienie bardzo istotne z punktu widzenia mikroekonomicznego, ponieważ gospodarstwa rolnicze są traktowane tak samo jak inne firmy i poddawane silnej konkurencji w ramach wspólnego rynku UE. Nowoczesny rachunek kosztów powinien stać się narzędziem umożliwiającym podniesienie efektywności prowadzonej działalności w szerszym kontekście idei zrównoważonego rozwoju. Również z punktu widzenia makroekonomicznego zagadnienie jest szczególnie istotne, ponieważ dla społeczeństwa ważne są ceny żywności oraz stan środowiska naturalnego i podtrzymanie jego trwałości. W sytuacji gdy rolnictwo jest dotowane z budżetu państwa oraz z wydzielonych funduszy UE, znajomość kosztów produkcji stanowi bardzo ważną informację uzasadniającą ich stosowanie. Wydaje się, że właściwie zaprojektowany system rachunku kosztów może stać się również zaczątkiem budowania fair trade ${ }^{9} \mathrm{w}$ agrobiznesie.

Ze względu na wysoki poziom kapitałochłonności produkcji rolniczej, szczególną uwagę należy zwrócić na koszty stałe związane z utrzymaniem potencjału produkcyjnego. Dużego znaczenia nabiera problem umiejętnego włączania kosztów stałych (potencjalnie stałych) do kalkulacji. Przykładem takiej kalkulacji jest obliczanie zmiany kosztu jednostkowego 1 cng (ciągnikogodziny) w zależności od poziomu wykorzystania ciągników w ciągu roku (tab. 1). Przyjęto następujące założenia do kalkulacji: ciągnik standardowy z napędem na cztery koła, moc znamionowa silnika w zakresie 60-74 kW (zapotrzebowanie na paliwo obliczono, przyjmując wartość średnią $67 \mathrm{~kW}$ ), średnia cena $5 \mathrm{zł} / \mathrm{kg}$, ekonomiczny potencjał wykorzystania środka trwałego 12 lat, wartość rezydualna (likwidacyjna) $0 \mathrm{zł}$, techniczny potencjał wykorzystania środka pracy $10000 \mathrm{~h}$, wartość początkowa $150000 \mathrm{zl}$, przy stopie procentowej $4 \% /$ rok, wskaźnik kosztów garażowania $2 \%$ i ubezpieczenia $2,5 \%$.

\footnotetext{
7 Przykładem takim jest rachunek kosztów działań - ABC (Activity Base Costing).

8 Bardzo interesującym podejściem wydaje się koncepcja kosztów docelowych (target costing).

9 Zadaniem fair trade jest tworzenie nowych możliwości dla gospodarczo zorganizowanych firm oraz działanie na rzecz przejrzystości gospodarowania i prowadzenia rachunkowości, tworzenia potencjału zwiększającego niezależność producentów, przejrzystości rozliczania, spłaty zobowiązań i stosowania „sprawiedliwych” (godziwych) cen, równości płci, bezpiecznych warunków pracy i ochrony środowiska.
} 
Tabela 1. Kalkulacja kosztów eksploatacji 1 cng przy zmiennym wykorzystaniu w roku*

\begin{tabular}{|c|c|c|c|c|c|c|}
\hline Wyszczególnienie & $\begin{array}{l}\text { Jedn. } \\
\text { miary }\end{array}$ & $\begin{array}{l}\mathrm{W}_{-1} . \\
250 \mathrm{~h}\end{array}$ & $\begin{array}{l}\mathrm{W} 2 . \\
500 \mathrm{~h}\end{array}$ & $\begin{array}{l}\text { W_3. } \\
83 \overline{3} \mathrm{~h}\end{array}$ & $\begin{array}{c}\mathrm{W}_{-} 4 . \\
1000 \mathrm{~h}\end{array}$ & $\begin{array}{c}\mathrm{W} 5 . \\
1500 \mathrm{~h}\end{array}$ \\
\hline Ekonomiczny potencjał wykorzystania & lata & 12 & 12 & 12 & 12 & 12 \\
\hline Techniczny potencjał wykorzystania & $\mathrm{H}$ & 10000 & 10000 & 10000 & 10000 & 10000 \\
\hline Wskaźnik kosztów napraw & - & 0,3 & 0,6 & 1 & 1,2 & 1,8 \\
\hline Wskaźnik kosztów garażowania & $\% /$ rok & 2 & 2 & 2 & 2 & 2 \\
\hline Podatki i ubezpieczenia & $\% /$ rok & 2,5 & 2,5 & 2,5 & 2,5 & 2,5 \\
\hline Cena zakupu ciągnika & $\mathrm{zł}$ & 150000 & 150000 & 150000 & 150000 & 150000 \\
\hline Cena paliwa $1 \mathrm{~kg}$ & $\mathrm{zl}$ & 5,0 & 5,0 & 5,0 & 5,0 & 5,0 \\
\hline Moc ciągnika & $\mathrm{kW}$ & 67 & 67 & 67 & 67 & 67 \\
\hline Zużycie paliwa & $\mathrm{kg} / \mathrm{cnh}$ & 10,79 & 10,79 & 10,79 & 10,79 & 10,79 \\
\hline Razem koszty użytkowania & $\mathrm{zl} / \mathrm{h}$ & 68,94 & 68,94 & 68,94 & 68,94 & 68,94 \\
\hline Amortyzacja & $\mathrm{zl} / \mathrm{h}$ & 50 & 25 & 15 & 15 & 15 \\
\hline Oprocentowanie kapitału & $\mathrm{zl} / \mathrm{h}$ & 12,00 & 6,00 & 3,60 & 3,00 & 2,00 \\
\hline Razem koszty utrzymania & $\mathrm{zt} / \mathrm{h}$ & 89,00 & 44,50 & 26,70 & 24,75 & 21,50 \\
\hline Koszt eksploatacji 1 cng & $\mathrm{zl} / \mathrm{h}$ & 157,94 & 113,44 & 95,64 & 93,69 & 90,44 \\
\hline
\end{tabular}

Źródło: obliczenia własne.

W kalkulacji wprowadzono 5 wariantów wykorzystania przykładowego ciągnika w ciągu roku. We wszystkich wariantach koszty użytkowania (zmienne) przypadające na $1 \mathrm{cng}$ były identyczne. Natomiast różnice obserwowano w kosztach utrzymania i konsekwencji. Analizując koszty 1 cng, można sformułować kluczowe pytania badawcze, istotne dla określenia metodyki rachunku kosztów w rolnictwie, w szczególności dotyczące rozliczania kosztów stałych:

- którego kosztu cng należy używać w kalkulacjach - kosztu użytkowania, który jest typowym kosztem zmiennym i kształtuje się na identycznym poziomie we wszystkich analizowanych wariantach, czy kosztu eksploatacji zawierającego koszty stałe?

- czy koszt eksploatacji 1 cng przy niskim wykorzystaniu ciągnika, obciążający koszt uprawy np. ziemniaków, może doprowadzić do wykazania nieopłacalności tej uprawy?

- czy w takiej sytuacji rolnik powinien zrezygnować z uprawy ziemniaków?

- jakie skutki spowoduje zaniechanie uprawy ziemniaków w stosunku do kosztów stałych?

- co należy robić (jakie decyzje podjąć), aby w sposób skuteczny poprawić sytuację?

- czy próg amortyzacji może być podstawą ustalania kosztów stałych stabilizowanych eksploatacji środków trwałych?

- czy właściwy rachunek kosztów przyczynia się do realizacji idei zrównoważonego rozwoju?

Kolejnym etapem badań było ustalenie korzyści i kosztów wdrażania koncepcji zrównoważonego rozwoju w konkretnych warunkach gospodarowania. Wyko- 
rzystano programowanie liniowe do weryfikacji wpływu ograniczeń związanych z przestrzeganiem zasad zrównoważonego rozwoju na dochodowość gospodarstw. Skonstruowano model gospodarstwa zrównoważonego, w którym wprowadzono następujące ograniczenia:

- udział 30\% trwałych użytków zielonych (TUZ) w użytkach rolnych (UR) bez możliwości transformacji na grunty orne (GO),

- maksymalny udział poszczególnych upraw: zboża 50\%, kukurydza 50\%, okopowe $25 \%$,

- obsada inwentarza do 1,5 DJP/ha UR,

- rolnik świadczy drobne usługi mechanizacyjne, wynajmuje pokój letnikom,

- żywienie w oparciu o własne pasze objętościowe i zboża.

Model gospodarstwa konwencjonalnego:

- możliwość transformacji TUZ na GO,

- udział poszczególnych upraw bez ograniczeń,

- obsada inwentarza do 2,5 DJP/ha UR,

- rolnik nie świadczy usług i nie prowadzi dodatkowej działalności,

- żywienie: możliwość zakupu pasz z zewnątrz.

Uzyskane wyniki dla tych dwóch modeli gospodarstw potwierdziły wpływ stosowanych ograniczeń z tytułu realizacji zasad zrównoważonego rozwoju na ich przychody i koszty. Gospodarstwo tradycyjne uzyskało przychody prawie o 50\% wyższe od gospodarstwa zrównoważonego. Jest to znacząca różnica (im większe ograniczenia, tym większa różnica), chociaż dochód rolniczy był wyższy jedynie o około $25 \%$ w gospodarstwie konwencjonalnym (koszty całkowite wzrosły o $35 \%$ ).

Wykorzystując wcześniej zdobyte doświadczenia przy stosowaniu programowania liniowego do weryfikacji poprawności zasad rachunku kosztów zmiennych i stałych, podjęto próbę weryfikacji poprawności koncepcji rachunku TDABC. W tym celu zbudowano model liniowy gospodarstwa mlecznego, odzwierciedlający relacje pomiędzy gospodarstwem domowym i gospodarstwem rolniczym, a także wprowadzono bilanse pozwalające na obliczanie kosztów metodą TDABC.

Wyniki badań modelowych w gospodarstwie z chowem krów mlecznych potwierdziły, że większość decyzji dotyczących działalności rolniczej mocno związana jest ze sferą prywatną (gospodarstwem domowym).

W celu wykazania, że model rachunku kosztów TDABC pozwala na podejmowanie optymalnych decyzji, podzielono zasoby gospodarstwa na stałe (niezależne od podejmowanych decyzji) i zmienne (które reagowały na zmiany warunków gospodarowania). Zgodnie z metodyką TDABC za najważniejszy cel tego rachunku uznano ustalenie poziomu kosztów bezużytecznych (pustych). Prześledzono dwa warianty rozwiązań modelu dotyczącego poziomu wykorzystania ciągników i ich kosztów w kontekście maksymalizacji dochodu ogólnego rodziny rolniczej:

1) przy założeniu, że zasoby cng są stałe i mogą być wykorzystane tylko $\mathrm{w}$ gospodarstwie; 
2) przy założeniu, że istnieje możliwość alternatywnego wykorzystania poza gospodarstwem (a więc zasoby cng przypisane gospodarstwu są zmienne).

Przeprowadzone obliczenia modelowe pozwoliły dojść do następujących wniosków:

- W wariancie 1. przy założeniu stałości zasobów wystąpiły koszty bezużyteczne z powodu niepełnego wykorzystania posiadanych zdolności produkcyjnych. Były one wyższe, gdy 1 cng była obciążona pełnymi kosztami (użytkowania i utrzymania), a niższe, gdy 1 cng była obciążona tylko kosztami zmiennymi (użytkowania) i w tym przypadku dochód rolniczy, dochód z gospodarstwa, a także dochód ogólny rodziny rolniczej, był wyższy. Z tego wynika wniosek, że przypisywanie kosztów utrzymania (stałych) potencjału produkcyjnego na nośniki kosztów, przy założeniu jego stałości, na etapie planowania i podejmowania decyzji jest rozwiązaniem niewłaściwym.

- W wariancie 2. nie wystąpiły koszty bezużyteczne, ponieważ niewykorzystane zasoby w gospodarstwie zostały zużyte poza gospodarstwem. W tym przypadku modelowany dochód rolniczy, dochód z gospodarstwa rolniczego, był nieco niższy, ale kategoria dochodu ogólnego rodziny rolniczej wyższa. Z wyników badań na modelach gospodarstw wynika, że stosowanie nowoczesnego rachunku kosztów, pozwalającego na rozliczanie na poszczególne działalności części kosztów stałych (utrzymania) potencjału produkcyjnego, wymaga dużej znajomości uwarunkowań badanego gospodarstwa pod kątem stałości i zmienności posiadanego potencjału i możliwych kierunków jego wykorzystania (również poza gospodarstwem).

Realizowanie strategii przywództwa kosztowego wymusza na producentach rolnych stałą dbałość o poziom ponoszonych nakładów i kosztów. W tym kontekście proponowany rachunek TDABC pozwala na lepsze rozliczanie kosztów pośrednich (stałych, skokowo zmiennych). Problem ten jest ważny, gdyż w rolnictwie udział kosztów pośrednich w ogólnych kosztach gospodarstw jest wysoki. Wykorzystanie TDABC pozwala zlokalizować i wskazać obszary nieracjonalnych decyzji gospodarstw w sferze posiadanego potencjału wytwórczego. Planowanie i świadome kształtowanie kosztów gospodarstwa wiejskiego (a więc i gospodarstwa domowego) jest koniecznością.

\section{Podsumowanie}

Dotychczasowe obawy, dotyczące niemożności przenoszenia zasad rachunku kosztów z działalności pozarolniczej do rolnictwa, nie potwierdzają się. Wyniki badań modelowych zastosowania nowoczesnych koncepcji rachunków kosztów w rolnictwie dają pozytywne rezultaty. Ograniczoność opracowania zmusza do skupienia uwagi na jednej wybranej koncepcji TDABC. Należy przyjąć, że wnioski co do innych koncepcji, takich jak rachunek kosztów docelowych z opcją KAIZEN, rachunek kosztów cyklu życia produktu, rachunek kosztów TQM czy też zasobowo-pro- 
cesowy rachunek kosztów (ZPRK) ${ }^{10}$, będą podobne. Dodatkowe ograniczenia wynikające $\mathrm{z}$ uwzględniania $\mathrm{w}$ ramach rachunku kosztów zasad zrównoważonego rozwoju nie zmieniają tego faktu.

Ogromny wpływ na praktyczne możliwości wdrożenia rachunku kosztów w gospodarstwie wiejskim będą mieli sami rolnicy, ale też konieczna jest pomoc z zewnątrz. Taką pomoc mogą oferować ośrodki doradztwa rolniczego (ODR). Wśród rolników przeważa podejście systemowe (holistyczne) i dążenie do podnoszenia wartości całego gospodarstwa wiejskiego. Dla rolników i ich rodzin gospodarstwo domowe jest równie ważne, a może ważniejsze od gospodarstwa produkcyjnego (rolniczego).

Wydaje się, że w warunkach naszego kraju główny ciężar oceny efektywności gospodarowania $\mathrm{w}$ rolnictwie i stosowania adekwatnych metod rachunku kosztów spoczywać powinien na instytucjach doradczych i badawczych, z jednoczesnym zapewnieniem podejmowania prób właściwego transferu wiedzy z tego zakresu do gospodarstw.

\section{Literatura}

Bereżnicka J., 2013, Wzrost i rozwój gospodarstw rodzinnych-studium teoretyczno-empiryczne, Rozprawy Naukowe i Monografie, Wydawnictwo SGGW, Warszawa.

Gędek S., 2009, Optymalizacja planów rocznych rodzinnego gospodarstwa rolnego, Rozprawy Naukowe i Monografie, Wydawnictwo SGGW, Warszawa.

Jóźwiak W., Kierul Z., 1985, Rachunek ekonomiczny w przedsiębiorstwie rolniczym może być prosty, PWRiL, Warszawa.

Kondraszuk T., 1987a, Po co oblicza się koszty jednostkowe?, Przegląd Organizacji, nr 7, s. 25-27.

Kondraszuk T., 1987b, Rachunek ekonomiczny tak - koszty jednostkowe nie!, Nowe Rolnictwo, nr 1, s.16-19.

Kondraszuk T., 2010, Rachunek kosztów działań sterowany czasem (TDABC) w rolnictwie, Prace Naukowe Uniwersytetu Ekonomicznego we Wrocławiu, nr 123, s. 211-219.

Kondraszuk T., 2013, Kalkulacje różnicowe $w$ rolnictwie na potrzeby wdrażania programów rolnośrodowiskowych, [w:] Dera A. (red.), Budżetowanie dziś i jutro, Wydawnictwo AGH, Kraków, s.130-141.

Kondraszuk T., 2016, Gospodarstwo wiejskie jako podstawa budowy modeli wspomagajacych podejmowanie decyzji w warunkach dążenia do zrównoważonego rozwoju, Prace Naukowe Uniwersytetu Ekonomicznego we Wrocławiu, nr 440, s. 296-304.

Manteuffel R., 1965, Rachunkowość rolnicza, tom 1, PWRiL, Warszawa.

Manteuffel R., 1984, Koszty jednostkowe i podstawy tworzenia cen w rolnictwie, Ekonomista, nr 1-2, s. $252-271$.

Zieliński T.M., 2014, Zasobowo-procesowy rachunek kosztów w przedsiębiorstwie, rozprawa doktorska, Uniwersytet Ekonomiczny w Poznaniu, Poznań.

Ziętara W., Kondraszuk T., 1986, Wątpliwa metoda, Życie Gospodarcze, nr 4.

Ziętara W., Kondraszuk T., 1987, Przydatność różnych kryteriów podziału kosztów dla potrzeb planowania w przedsiębiorstwie rolniczym, Roczniki Nauk Rolniczych, seria G, t. 84, z. 3, s. 25-38.

${ }^{10}$ Więcej o ZPRK [Zieliński 2014]. 